\title{
Cyclic nucleotide-regulated channels (CNG) in GtoPdb v.2021.3
}

Elvir Becirovic ${ }^{1}$, Martin Biel $^{1}$, Stefanie Fenske ${ }^{1}$, Verena Hammelmann ${ }^{1}$, Franz Hofmann ${ }^{2}$ and U. Benjamin Kaupp ${ }^{3}$

1. Ludwig-Maximilians-Universität, Germany

2. Technische Universität München, Germany

3. Forschungszentrum Jülich, Germany

\begin{abstract}
Cyclic nucleotide-gated (CNG) channels are responsible for signalling in the primary sensory cells of the vertebrate visual and olfactory systems. CNG channels are voltage-independent cation channels formed as tetramers. Each subunit has 6TM, with the pore-forming domain between TM5 and TM6. CNG channels were first found in rod photoreceptors [83, 120], where light signals through rhodopsin and transducin to stimulate phosphodiesterase and reduce intracellular cyclic GMP level. This results in a closure of CNG channels and a reduced 'dark current'. Similar channels were found in the cilia of olfactory neurons [181] and the pineal gland [71]. The cyclic nucleotides bind to a domain in the $\mathrm{C}$ terminus of the subunit protein: other channels directly binding cyclic nucleotides include hyperolarisation-activated, cyclic nucleotide-gated channels (HCN), ether-a-go-go and certain plant potassium channels.
\end{abstract}

The HCN channels are cation channels that are activated by hyperpolarisation at voltages negative to $\sim-50 \mathrm{mV}$. The cyclic nucleotides cyclic AMP and cyclic GMP directly bind to the cyclic nucleotidebinding domain of HCN channels and shift their activation curves to more positive voltages, thereby enhancing channel activity. HCN channels underlie pacemaker currents found in many excitable cells including cardiac cells and neurons $[64,192]$. In native cells, these currents have a variety of names, such as $I_{\mathrm{h}}, I_{\mathrm{q}}$ and $I_{\mathrm{f}}$. The four known HCN channels have six transmembrane domains and form tetramers. It is believed that the channels can form heteromers with each other, as has been shown for HCN1 and HCN4 [2]. High resolution structural studies of CNG and HCN channels has provided insight into the the gating processes of these channels [139, 146, 140]. A standardised nomenclature for CNG and HCN channels has been proposed by the NC-IUPHAR Subcommittee on voltage-gated ion channels [108].

\section{Contents}

This is a citation summary for Cyclic nucleotide-regulated channels (CNG) in the Guide to Pharmacology database (GtoPdb). It exists purely as an adjunct to the database to facilitate the recognition of citations to and from the database by citation analyzers. Readers will almost certainly want to visit the relevant sections of the database which are given here under database links.

GtoPdb is an expert-driven guide to pharmacological targets and the substances that act on them. GtoPdb is a reference work which is most usefully represented as an on-line database. As in any publication this work should be appropriately cited, and the papers it cites should also be recognized. This document provides a citation for the relevant parts of the database, and also provides a reference list for the research cited by those parts. For further details see [41].

Please note that the database version for the citations given in GtoPdb are to the most recent preceding version in which the family or its subfamilies and targets were substantially changed. The links below are to the current version. If you need to consult the cited version, rather than the most recent version, please contact the GtoPdb curators.

\section{Database links}


Cyclic nucleotide-regulated channels (CNG)

https://www.guidetopharmacology.org/GRAC/FamilyDisplayForward?familyId=71

Introduction to Cyclic nucleotide-regulated channels (CNG)

https://www.guidetopharmacology.org/GRAC/FamilyIntroductionForward?familyId=71

Channels and Subunits

CNGA1

https://www.guidetopharmacology.org/GRAC/ObjectDisplayForward?objectId=394 CNGA2

https://www.guidetopharmacology.org/GRAC/ObjectDisplayForward?objectId=395 CNGA3

https://www.guidetopharmacology.org/GRAC/ObjectDisplayForward?objectId=396 CNGA4

https://www.guidetopharmacology.org/GRAC/ObjectDisplayForward?objectId=397 CNGB1

https://www.guidetopharmacology.org/GRAC/ObjectDisplayForward?objectId=398 CNGB3

https://www.guidetopharmacology.org/GRAC/ObjectDisplayForward?objectId=399 HCN1

https://www.guidetopharmacology.org/GRAC/ObjectDisplayForward?objectId $=400$ HCN2

https://www.guidetopharmacology.org/GRAC/ObjectDisplayForward?objectId=401 HCN3

https://www.guidetopharmacology.org/GRAC/ObjectDisplayForward?objectId=402 HCN4

https://www.guidetopharmacology.org/GRAC/ObjectDisplayForward?objectId=403

\section{References}

1. Ahuja Y, Kohl S and Traboulsi EI. (2008) CNGA3 mutations in two United Arab Emirates families with achromatopsia. Mol Vis 14: 1293-7 [PMID:18636117]

2. Altomare C, Terragni B, Brioschi C, Milanesi R, Pagliuca C, Viscomi C, Moroni A, Baruscotti M and DiFrancesco D. (2003) Heteromeric HCN1-HCN4 channels: a comparison with native pacemaker channels from the rabbit sinoatrial node. J Physiol (Lond.) 549: 347-59 [PMID:12702747]

3. Ardell MD, Aragon I, Oliveira L, Porche GE, Burke E and Pittler SJ. (1996) The beta subunit of human rod photoreceptor cGMP-gated cation channel is generated from a complex transcription unit. FEBS Lett 389: 213-8 [PMID:8766832]

4. Ardell MD, Bedsole DL, Schoborg RV and Pittler SJ. (2000) Genomic organization of the human rod photoreceptor cGMP-gated cation channel beta-subunit gene. Gene 245: 311-8 [PMID:10717482]

5. Ardell MD, Makhija AK, Oliveira L, Miniou P, Viegas-Péquignot E and Pittler SJ. (1995) cDNA, gene structure, and chromosomal localization of human GAR1 (CNCG3L), a homolog of the third subunit of bovine photoreceptor cGMP-gated channel. Genomics 28: 32-8 [PMID:7590744]

6. Azam M, Collin RW, Shah ST, Shah AA, Khan MI, Hussain A, Sadeque A, Strom TM, Thiadens AA and Roosing S et al.. (2010) Novel CNGA3 and CNGB3 mutations in two Pakistani families with achromatopsia. Mol Vis 16: 774-81 [PMID:20454696]

7. Bankston JR, Camp SS, DiMaio F, Lewis AS, Chetkovich DM and Zagotta WN. (2012) Structure and stoichiometry of an accessory subunit TRIP8b interaction with hyperpolarization-activated cyclic nucleotide-gated channels. Proc Natl Acad Sci USA 109: 7899-904 [PMID:22550182]

8. Barbuti A and DiFrancesco D. (2008) Control of cardiac rate by "funny" channels in health and disease. Ann N Y Acad Sci 1123: 213-23 [PMID:18375593]

9. Barbuti A, Scavone A, Mazzocchi N, Terragni B, Baruscotti M and Difrancesco D. (2012) A caveolin-binding domain in the HCN4 channels mediates functional interaction with caveolin proteins. J Mol Cell Cardiol 53: 187-95 [PMID:22659290]

10. Bareil C, Hamel CP, Delague V, Arnaud B, Demaille J and Claustres M. (2001) Segregation of a mutation in CNGB1 encoding the beta-subunit of the rod cGMP-gated channel in a family with autosomal recessive retinitis pigmentosa. Hum Genet 108: 328-34 [PMID:11379879]

11. Barnstable CJ and Wei J-Y. (1995) Isolation and characterization of the alpha-subunit of the rat rod photoreceptor cGMP-gated cation channel. J Mol Neurosci 6: 289-302 [PMID:8860239]

12. Baruscotti M, Bucchi A and Difrancesco D. (2005) Physiology and pharmacology of the cardiac pacemaker ("funny") current. Pharmacol Ther 107: 59-79 [PMID:15963351]

13. Baruscotti M, Bucchi A, Viscomi C, Mandelli G, Consalez G, Gnecchi-Rusconi T, Montano N, Casali KR, Micheloni S and Barbuti A et al.. (2011) Deep bradycardia and heart block caused by inducible cardiac-specific knockout of the pacemaker channel gene Hcn4. Proc Natl Acad Sci USA 108: 1705-10 [PMID:21220308]

14. Bauer PJ and Drechsler M. (1992) Association of cyclic GMP-gated channels and $\mathrm{Na}(+)-\mathrm{Ca}(2+)-$ 
$\mathrm{K}+$ exchangers in bovine retinal rod outer segment plasma membranes. J Physiol (Lond.) 451: 109-31 [PMID:1328615]

15. Becirovic E, Nakova K, Hammelmann V, Hennel R, Biel M and Michalakis S. (2010) The retinitis pigmentosa mutation c.3444+1G>A in CNGB1 results in skipping of exon 32. PLoS ONE 5: e8969 [PMID:20126465]

16. Bender RA, Soleymani SV, Brewster AL, Nguyen ST, Beck H, Mathern GW and Baram TZ. (2003) Enhanced expression of a specific hyperpolarization-activated cyclic nucleotide-gated cation channel (HCN) in surviving dentate gyrus granule cells of human and experimental epileptic hippocampus. J Neurosci 23: 6826-36 [PMID:12890777]

17. Berghard A, Buck LB and Liman ER. (1996) Evidence for distinct signaling mechanisms in two mammalian olfactory sense organs. Proc Natl Acad Sci USA 93: 2365-9 [PMID:8637879]

18. Biel M and Michalakis S. (2009) Cyclic nucleotide-gated channels. In Handbook of Experimental Pharmacology Edited by Schmidt HH, Hofmann F, Stasch JP: Springer: 111-136 [ISBN: 9783540689607]

19. Biel M, Seeliger M, Pfeifer A, Kohler K, Gerstner A, Ludwig A, Jaissle G, Fauser S, Zrenner E and Hofmann F. (1999) Selective loss of cone function in mice lacking the cyclic nucleotidegated channel CNG3. Proc Natl Acad Sci USA 96: 7553-7 [PMID:10377453]

20. Biel M, Wahl-Schott C, Michalakis S and Zong X. (2009) Hyperpolarization-activated cation channels: from genes to function. Physiol Rev 89: 847-85 [PMID:19584315]

21. Biel M, Zong X, Distler M, Bosse E, Klugbauer N, Murakami M, Flockerzi V and Hofmann F. (1994) Another member of the cyclic nucleotide-gated channel family, expressed in testis, kidney, and heart. Proc Natl Acad Sci USA 91: 3505-9 [PMID:8170936]

22. Bois P, Bescond J, Renaudon B and Lenfant J. (1996) Mode of action of bradycardic agent, S 16257, on ionic currents of rabbit sinoatrial node cells. Br J Pharmacol 118: 1051-7 [PMID:8799581]

23. Bonin RP, Zurek AA, Yu J, Bayliss DA and Orser BA. (2013) Hyperpolarization-activated current (In) is reduced in hippocampal neurons from Gabra5-/- mice. PLoS ONE 8: e58679 [PMID:23516534]

24. Borlak J and Thum T. (2003) Hallmarks of ion channel gene expression in end-stage heart failure. FASEB J 17: 1592-608 [PMID:12958166]

25. BoSmith RE, Briggs I and Sturgess NC. (1993) Inhibitory actions of ZENECA ZD7288 on wholecell hyperpolarization activated inward current (If) in guinea-pig dissociated sinoatrial node cells. Br J Pharmacol 110: 343-9 [PMID:7693281]

26. Bradley J, Bönigk W, Yau KW and Frings S. (2004) Calmodulin permanently associates with rat olfactory CNG channels under native conditions. Nat Neurosci 7: 705-10 [PMID:15195096]

27. Bradley J, Frings S, Yau KW and Reed R. (2001) Nomenclature for ion channel subunits. Science 294: 2095-6 [PMID:11764791]

28. Bradley J, Li J, Davidson N, Lester HA and Zinn K. (1994) Heteromeric olfactory cyclic nucleotide-gated channels: a subunit that confers increased sensitivity to cAMP. Proc Natl Acad Sci USA 91: 8890-4 [PMID:7522325]

29. Bradley J, Reisert J and Frings S. (2005) Regulation of cyclic nucleotide-gated channels. Curr Opin Neurobiol 15: 343-9 [PMID:15922582]

30. Bradley J, Reuter D and Frings S. (2001) Facilitation of calmodulin-mediated odor adaptation by cAMP-gated channel subunits. Science 294: 2176-8 [PMID:11739960]

31. Bradley J, Zhang Y, Bakin R, Lester HA, Ronnett GV and Zinn K. (1997) Functional expression of the heteromeric "olfactory" cyclic nucleotide-gated channel in the hippocampus: a potential effector of synaptic plasticity in brain neurons. J Neurosci 17: 1993-2005 [PMID:9045728]

32. Brady JD, Rich ED, Martens JR, Karpen JW, Varnum MD and Brown RL. (2006) Interplay between PIP3 and calmodulin regulation of olfactory cyclic nucleotide-gated channels. Proc Natl Acad Sci USA 103: 15635-40 [PMID:17032767]

33. Brandt MC, Endres-Becker J, Zagidullin N, Motloch LJ, Er F, Rottlaender D, Michels G, Herzig S and Hoppe UC. (2009) Effects of KCNE2 on HCN isoforms: distinct modulation of membrane expression and single channel properties. Am J Physiol Heart Circ Physiol 297: H355-63 [PMID:19429827]

34. Brown RL, Haley TL, West KA and Crabb JW. (1999) Pseudechetoxin: a peptide blocker of cyclic nucleotide-gated ion channels. Proc Natl Acad Sci USA 96: 754-9 [PMID:9892706]

35. Brown RL, Lynch LL, Haley TL and Arsanjani R. (2003) Pseudechetoxin binds to the pore turret of cyclic nucleotide-gated ion channels. J Gen Physiol 122: 749-60 [PMID:14638933]

36. Brunet LJ, Gold GH and Ngai J. (1996) General anosmia caused by a targeted disruption of the mouse olfactory cyclic nucleotide-gated cation channel. Neuron 17: 681-93 [PMID:8893025]

37. Bucchi A, Barbuti A, Difrancesco D and Baruscotti M. (2012) Funny Current and Cardiac Rhythm: Insights from HCN Knockout and Transgenic Mouse Models. Front Physiol 3: 240 [PMID:22783204]

38. Bucchi A, Baruscotti M and DiFrancesco D. (2002) Current-dependent block of rabbit sino-atrial node I(f) channels by ivabradine. J Gen Physiol 120: 1-13 [PMID:12084770] 
39. Bucchi A, Tognati A, Milanesi R, Baruscotti M and DiFrancesco D. (2006) Properties of ivabradine-induced block of HCN1 and HCN4 pacemaker channels. J Physiol (Lond.) 572: 33546 [PMID:16484306]

40. Budde T, Caputi L, Kanyshkova T, Staak R, Abrahamczik C, Munsch T and Pape HC. (2005) Impaired regulation of thalamic pacemaker channels through an imbalance of subunit expression in absence epilepsy. $J$ Neurosci 25: 9871-82 [PMID:16251434]

41. Buneman P, Christie G, Davies JA, Dimitrellou R, Harding SD, Pawson AJ, Sharman JL and Wu Y. (2020) Why data citation isn't working, and what to do about it Database 2020 [PMID:32367113]

42. Bönigk W, Bradley J, Müller F, Sesti F, Boekhoff I, Ronnett GV, Kaupp UB and Frings S. (1999) The native rat olfactory cyclic nucleotide-gated channel is composed of three distinct subunits. $J$ Neurosci 19: 5332-47 [PMID:10377344]

43. Cacheaux LP, Topf N, Tibbs GR, Schaefer UR, Levi R, Harrison NL, Abbott GW and Goldstein PA. (2005) Impairment of hyperpolarization-activated, cyclic nucleotide-gated channel function by the intravenous general anesthetic propofol. J Pharmacol Exp Ther 315: 517-25 [PMID:16033909]

44. Cao-Ehlker X, Zong X, Hammelmann V, Gruner C, Fenske S, Michalakis S, Wahl-Schott C and Biel M. (2013) Up-regulation of hyperpolarization-activated cyclic nucleotide-gated channel 3 (HCN3) by specific interaction with $\mathrm{K}+$ channel tetramerization domain-containing protein 3 (KCTD3). J Biol Chem 288: 7580-9 [PMID:23382386]

45. Carrisoza-Gaytán R, Rangel C, Salvador C, Saldaña-Meyer R, Escalona C, Satlin LM, Liu W, Zavilowitz B, Trujillo J and Bobadilla NA et al.. (2011) The hyperpolarization-activated cyclic nucleotide-gated HCN2 channel transports ammonium in the distal nephron. Kidney Int 80: 83240 [PMID:21796099]

46. Cerbai E and Mugelli A. (2006) I(f) in non-pacemaker cells: role and pharmacological implications. Pharmacol Res 53: 416-23 [PMID:16713285]

47. Chan CS, Glajch KE, Gertler TS, Guzman JN, Mercer JN, Lewis AS, Goldberg AB, Tkatch T, Shigemoto R and Fleming SM et al.. (2011) HCN channelopathy in external globus pallidus neurons in models of Parkinson's disease. Nat Neurosci 14: 85-92 [PMID:21076425]

48. Chan CS, Shigemoto R, Mercer JN and Surmeier DJ. (2004) HCN2 and HCN1 channels govern the regularity of autonomous pacemaking and synaptic resetting in globus pallidus neurons. $J$ Neurosci 24: 9921-32 [PMID:15525777]

49. Chen S, Wang J and Siegelbaum SA. (2001) Properties of hyperpolarization-activated pacemaker current defined by coassembly of HCN1 and HCN2 subunits and basal modulation by cyclic nucleotide. J Gen Physiol 117: 491-504 [PMID:11331358]

50. Chen TY, Illing M, Molday LL, Hsu YT, Yau KW and Molday RS. (1994) Subunit 2 (or beta) of retinal rod cGMP-gated cation channel is a component of the $240-\mathrm{kDa}$ channel-associated protein and mediates Ca(2+)-calmodulin modulation. Proc Natl Acad Sci USA 91: 11757-61 [PMID:7526403]

51. Chen TY, Peng YW, Dhallan RS, Ahamed B, Reed RR and Yau KW. (1993) A new subunit of the cyclic nucleotide-gated cation channel in retinal rods. Nature 362: 764-7 [PMID:7682292]

52. Chen TY and Yau KW. (1994) Direct modulation by Ca(2+)-calmodulin of cyclic nucleotideactivated channel of rat olfactory receptor neurons. Nature 368: 545-8 [PMID:7511217]

53. Chen X, Shu S, Kennedy DP, Willcox SC and Bayliss DA. (2009) Subunit-specific effects of isoflurane on neuronal Ih in HCN1 knockout mice. J Neurophysiol 101: 129-40 [PMID:18971302]

54. Colville CA and Molday RS. (1996) Primary structure and expression of the human beta-subunit and related proteins of the rod photoreceptor cGMP-gated channel. J Biol Chem 271: 32968-74 [PMID:8955140]

55. Dean DM, Nguitragool W, Miri A, McCabe SL and Zimmerman AL. (2002) All-trans-retinal shuts down rod cyclic nucleotide-gated ion channels: a novel role for photoreceptor retinoids in the response to bright light? Proc Natl Acad Sci USA 99: 8372-7 [PMID:12034887]

56. DeBerg HA, Bankston JR, Rosenbaum JC, Brzovic PS, Zagotta WN and Stoll S. (2015) Structural mechanism for the regulation of HCN ion channels by the accessory protein TRIP8b. Structure 23: 734-44 [PMID:25800552]

57. Decher N, Bundis F, Vajna R and Steinmeyer K. (2003) KCNE2 modulates current amplitudes and activation kinetics of HCN4: influence of KCNE family members on HCN4 currents. Pflugers Arch 446: 633-40 [PMID:12856183]

58. Dekker JP and Yellen G. (2006) Cooperative gating between single HCN pacemaker channels. $J$ Gen Physiol 128: 561-7 [PMID:17043149]

59. Del Lungo M, Melchiorre M, Guandalini L, Sartiani L, Mugelli A, Koncz I, Szel T, Varro A, Romanelli MN and Cerbai E. (2012) Novel blockers of hyperpolarization-activated current with isoform selectivity in recombinant cells and native tissue. Br J Pharmacol 166: 602-16 [PMID:22091830]

60. Della Santina L, Piano I, Cangiano L, Caputo A, Ludwig A, Cervetto L and Gargini C. (2012) 
Processing of retinal signals in normal and HCN deficient mice. PLoS ONE 7: e29812 [PMID:22279546]

61. Dhallan RS, Macke JP, Eddy RL, Shows TB, Reed RR, Yau KW and Nathans J. (1992) Human rod photoreceptor cGMP-gated channel: amino acid sequence, gene structure, and functional expression. J Neurosci 12: 3248-56 [PMID:1379636]

62. Dhallan RS, Yau KW, Schrader KA and Reed RR. (1990) Primary structure and functional expression of a cyclic nucleotide-activated channel from olfactory neurons. Nature 347: 184-7 [PMID:1697649]

63. Dibbens LM, Reid CA, Hodgson B, Thomas EA, Phillips AM, Gazina E, Cromer BA, Clarke AL, Baram TZ and Scheffer IE et al.. (2010) Augmented currents of an HCN2 variant in patients with febrile seizure syndromes. Ann Neurol 67: 542-6 [PMID:20437590]

64. DiFrancesco D. (1993) Pacemaker mechanisms in cardiac tissue. Annu Rev Physiol 55: $455-72$ [PMID:7682045]

65. DiFrancesco JC, Barbuti A, Milanesi R, Coco S, Bucchi A, Bottelli G, Ferrarese C, Franceschetti $\mathrm{S}$, Terragni B and Baruscotti $\mathrm{M}$ et al.. (2011) Recessive loss-of-function mutation in the pacemaker HCN2 channel causing increased neuronal excitability in a patient with idiopathic generalized epilepsy. J Neurosci 31: 17327-37 [PMID:22131395]

66. DiFrancesco JC and DiFrancesco D. (2015) Dysfunctional HCN ion channels in neurological diseases. Front Cell Neurosci 6: 174 [PMID:25805968]

67. Ding C, Potter ED, Qiu W, Coon SL, Levine MA and Guggino SE. (1997) Cloning and widespread distribution of the rat rod-type cyclic nucleotide-gated cation channel. Am J Physiol 272: C133544 [PMID:9142860]

68. Ding XQ, Harry CS, Umino Y, Matveev AV, Fliesler SJ and Barlow RB. (2009) Impaired cone function and cone degeneration resulting from CNGB3 deficiency: down-regulation of CNGA3 biosynthesis as a potential mechanism. Hum Mol Genet 18: 4770-80 [PMID:19767295]

69. Ding XQ, Matveev A, Singh A, Komori N and Matsumoto H. (2012) Biochemical characterization of cone cyclic nucleotide-gated (CNG) channel using the infrared fluorescence detection system. Adv Exp Med Biol 723: 769-75 [PMID:22183405]

70. Drescher MJ, Barretto RL, Chaturvedi D, Beisel KW, Hatfield JS, Khan KM and Drescher DG. (2002) Expression of subunits for the cAMP-sensitive 'olfactory' cyclic nucleotide-gated ion channel in the cochlea: implications for signal transduction. Brain Res Mol Brain Res 98: 1-14 [PMID:11834291]

71. Dryer SE and Henderson D. (1991) A cyclic GMP-activated channel in dissociated cells of the chick pineal gland. Nature 353: 756-8 [PMID:1719422]

72. Dryja TP, Finn JT, Peng YW, McGee TL, Berson EL and Yau KW. (1995) Mutations in the gene encoding the alpha subunit of the rod cGMP-gated channel in autosomal recessive retinitis pigmentosa. Proc Natl Acad Sci USA 92: 10177-81 [PMID:7479749]

73. Du L, Wang SJ, Cui J, He WJ and Ruan HZ. (2013) Inhibition of HCN channels within the periaqueductal gray attenuates neuropathic pain in rats. Behav Neurosci 127: 325-9 [PMID:23398435]

74. Duhme N, Schweizer PA, Thomas D, Becker R, Schröter J, Barends TR, Schlichting I, Draguhn A, Bruehl C and Katus HA et al.. (2013) Altered HCN4 channel C-linker interaction is associated with familial tachycardia-bradycardia syndrome and atrial fibrillation. Eur Heart J 34: 2768-75 [PMID:23178648]

75. Dzeja C, Hagen V, Kaupp UB and Frings S. (1999) Ca2+ permeation in cyclic nucleotide-gated channels. EMBO J 18: 131-44 [PMID:9878057]

76. El-Kholy W, MacDonald PE, Fox JM, Bhattacharjee A, Xue T, Gao X, Zhang Y, Stieber J, Li RA and Tsushima RG et al.. (2007) Hyperpolarization-activated cyclic nucleotide-gated channels in pancreatic beta-cells. Mol Endocrinol 21: 753-64 [PMID:17158221]

77. Emery EC, Young GT, Berrocoso EM, Chen L and McNaughton PA. (2011) HCN2 ion channels play a central role in inflammatory and neuropathic pain. Science 333: 1462-6 [PMID:21903816]

78. Emery EC, Young GT and McNaughton PA. (2012) HCN2 ion channels: an emerging role as the pacemakers of pain. Trends Pharmacol Sci 33: 456-63 [PMID:22613784]

79. Fenske S, Krause S, Biel M and Wahl-Schott C. (2011) The role of HCN channels in ventricular repolarization. Trends Cardiovasc Med 21: 216-20 [PMID:22902068]

80. Fenske S, Krause SC, Hassan SI, Becirovic E, Auer F, Bernard R, Kupatt C, Lange P, Ziegler T and Wotjak CT et al.. (2013) Sick sinus syndrome in HCN1-deficient mice. Circulation 128: 2585-94 [PMID:24218458]

81. Fenske S, Mader R, Scharr A, Paparizos C, Cao-Ehlker X, Michalakis S, Shaltiel L, Weidinger M, Stieber J and Feil S et al.. (2011) HCN3 contributes to the ventricular action potential waveform in the murine heart. Circ Res 109: 1015-23 [PMID:21903939]

82. Fernández-Velasco M, Goren N, Benito G, Blanco-Rivero J, Boscá L and Delgado C. (2003) Regional distribution of hyperpolarization-activated current (If) and hyperpolarization-activated cyclic nucleotide-gated channel mRNA expression in ventricular cells from control and 
hypertrophied rat hearts. J Physiol (Lond.) 553: 395-405 [PMID:14514868]

83. Fesenko EE, Kolesnikov SS and Lyubarsky AL. (1985) Induction by cyclic GMP of cationic conductance in plasma membrane of retinal rod outer segment. Nature 313: 310-3 [PMID:2578616]

84. Finn JT, Krautwurst D, Schroeder JE, Chen TY, Reed RR and Yau KW. (1998) Functional coassembly among subunits of cyclic-nucleotide-activated, nonselective cation channels, and across species from nematode to human. Biophys J 74: 1333-45 [PMID:9512030]

85. Flynn GE, Black KD, Islas LD, Sankaran B and Zagotta WN. (2007) Structure and rearrangements in the carboxy-terminal region of SpIH channels. Structure 15: 671-82 [PMID:17562314]

86. Frings S, Seifert R, Godde M and Kaupp UB. (1995) Profoundly different calcium permeation and blockage determine the specific function of distinct cyclic nucleotide-gated channels. Neuron 15: 169-79 [PMID:7542461]

87. Gauss R, Seifert R and Kaupp UB. (1998) Molecular identification of a hyperpolarizationactivated channel in sea urchin sperm. Nature 393: 583-7 [PMID:9634235]

88. Gerstner A, Zong X, Hofmann F and Biel M. (2000) Molecular cloning and functional characterization of a new modulatory cyclic nucleotide-gated channel subunit from mouse retina. J Neurosci 20: 1324-32 [PMID:10662822]

89. Giocomo LM, Hussaini SA, Zheng F, Kandel ER, Moser MB and Moser EI. (2011) Grid cells use HCN1 channels for spatial scaling. Cell 147: 1159-70 [PMID:22100643]

90. González-del Pozo M, Borrego S, Barragán I, Pieras JI, Santoyo J, Matamala N, Naranjo B, Dopazo J and Antiñolo G. (2011) Mutation screening of multiple genes in Spanish patients with autosomal recessive retinitis pigmentosa by targeted resequencing. PLOS ONE 6: e27894 [PMID:22164218]

91. Gordon SE and Zagotta WN. (1995) A histidine residue associated with the gate of the cyclic nucleotide-activated channels in rod photoreceptors. Neuron 14: 177-83 [PMID:7530019]

92. Goto-Omoto S, Hayashi T, Gekka T, Kubo A, Takeuchi T and Kitahara K. (2006) Compound heterozygous CNGA3 mutations (R436W, L633P) in a Japanese patient with congenital achromatopsia. Vis Neurosci 23: 395-402 [PMID:16961972]

93. Graf EM, Heubach JF and Ravens U. (2001) The hyperpolarization-activated current If in ventricular myocytes of non-transgenic and beta2-adrenoceptor overexpressing mice. Naunyn Schmiedebergs Arch Pharmacol 364: 131-9 [PMID:11534852]

94. Gravante B, Barbuti A, Milanesi R, Zappi I, Viscomi C and DiFrancesco D. (2004) Interaction of the pacemaker channel HCN1 with filamin A. J Biol Chem 279: 43847-53 [PMID:15292205]

95. Greene D, Kang S, Kosenko A and Hoshi N. (2012) Adrenergic regulation of HCN4 channel requires protein association with $\beta 2$-adrenergic receptor. J Biol Chem 287: 23690-7 [PMID:22613709]

96. Grunwald ME, Yu WP, Yu HH and Yau KW. (1998) Identification of a domain on the beta-subunit of the rod cGMP-gated cation channel that mediates inhibition by calcium-calmodulin. J Biol Chem 273: 9148-57 [PMID:9535905]

97. Gupta VK, Rajala A, Daly RJ and Rajala RV. (2010) Growth factor receptor-bound protein 14: a new modulator of photoreceptor-specific cyclic-nucleotide-gated channel. EMBO Rep 11: 861-7 [PMID:20890309]

98. Hammelmann V, Zong X, Hofmann F, Michalakis S and Biel M. (2011) The cGMP-dependent protein kinase II Is an inhibitory modulator of the hyperpolarization-activated HCN2 channel. PLOS ONE 6: e17078 [PMID:21347269]

99. Han Y, Noam Y, Lewis AS, Gallagher JJ, Wadman WJ, Baram TZ and Chetkovich DM. (2011) Trafficking and gating of hyperpolarization-activated cyclic nucleotide-gated channels are regulated by interaction with tetratricopeptide repeat-containing Rab8b-interacting protein (TRIP8b) and cyclic AMP at distinct sites. J Biol Chem 286: 20823-34 [PMID:21504900]

100. Hartong DT, Berson EL and Dryja TP. (2006) Retinitis pigmentosa. Lancet 368: 1795-809 [PMID:17113430]

101. Harzheim D, Pfeiffer KH, Fabritz L, Kremmer E, Buch T, Waisman A, Kirchhof P, Kaupp UB and Seifert R. (2008) Cardiac pacemaker function of HCN4 channels in mice is confined to embryonic development and requires cyclic AMP. EMBO J 27: 692-703 [PMID:18219271]

102. Haynes LW. (1992) Block of the cyclic GMP-gated channel of vertebrate rod and cone photoreceptors by l-cis-diltiazem. J Gen Physiol 100: 783-801 [PMID:1282145]

103. He P, Deng J, Zhong X, Zhou Z, Song B and Li L. (2012) Identification of a hyperpolarizationactivated cyclic nucleotide-gated channel and its subtypes in the urinary bladder of the rat. Urology 79: 1411.e7-13 [PMID:22446339]

104. Herrmann S, Hofmann F, Stieber J and Ludwig A. (2012) HCN channels in the heart: lessons from mouse mutants. Br J Pharmacol 166: 501-9 [PMID:22141457]

105. Herrmann S, Layh B and Ludwig A. (2011) Novel insights into the distribution of cardiac HCN channels: an expression study in the mouse heart. J Mol Cell Cardiol 51: 997-1006 [PMID:21945247] 
106. Hirano AA, Hack I, Wässle H and Duvoisin RM. (2000) Cloning and immunocytochemical localization of a cyclic nucleotide-gated channel alpha-subunit to all cone photoreceptors in the mouse retina. J Comp Neurol 421: 80-94 [PMID:10813773]

107. Hoesl E, Stieber J, Herrmann S, Feil S, Tybl E, Hofmann F, Feil R and Ludwig A. (2008) Tamoxifen-inducible gene deletion in the cardiac conduction system. J Mol Cell Cardiol 45: 62-9 [PMID:18538341]

108. Hofmann F, Biel M and Kaupp UB. (2005) International Union of Pharmacology. LI. Nomenclature and structure-function relationships of cyclic nucleotide-regulated channels. Pharmacol Rev 57: 455-62 [PMID:16382102]

109. Horwitz GC, Lelli A, Géléoc GS and Holt JR. (2010) HCN channels are not required for mechanotransduction in sensory hair cells of the mouse inner ear. PLOS ONE 5: e8627 [PMID:20062532]

110. Horwitz GC, Risner-Janiczek JR, Jones SM and Holt JR. (2011) HCN channels expressed in the inner ear are necessary for normal balance function. J Neurosci 31: 16814-25 [PMID:22090507]

111. Hsu YT and Molday RS. (1994) Interaction of calmodulin with the cyclic GMP-gated channel of rod photoreceptor cells. Modulation of activity, affinity purification, and localization. J Biol Chem 269: 29765-70 [PMID:7525588]

112. Hurtado R, Bub G and Herzlinger D. (2010) The pelvis-kidney junction contains HCN3, a hyperpolarization-activated cation channel that triggers ureter peristalsis. Kidney Int 77: 500-8 [PMID:20032965]

113. Hüttl S, Michalakis S, Seeliger M, Luo DG, Acar N, Geiger H, Hudl K, Mader R, Haverkamp S and Moser $\mathrm{M}$ et al.. (2005) Impaired channel targeting and retinal degeneration in mice lacking the cyclic nucleotide-gated channel subunit CNGB1. J Neurosci 25: 130-8 [PMID:15634774]

114. Ishii TM, Takano M, Xie LH, Noma A and Ohmori H. (1999) Molecular characterization of the hyperpolarization-activated cation channel in rabbit heart sinoatrial node. J Biol Chem 274: 12835-9 [PMID:10212270]

115. Jenkins PM, Zhang L, Thomas G and Martens JR. (2009) PACS-1 mediates phosphorylationdependent ciliary trafficking of the cyclic-nucleotide-gated channel in olfactory sensory neurons. J Neurosci 29: 10541-51 [PMID:19710307]

116. Jin ZB, Mandai M, Yokota T, Higuchi K, Ohmori K, Ohtsuki F, Takakura S, Itabashi T, Wada Y and Akimoto $\mathrm{M}$ et al.. (2008) Identifying pathogenic genetic background of simplex or multiplex retinitis pigmentosa patients: a large scale mutation screening study. J Med Genet 45: 465-72 [PMID:18310263]

117. Johnson S, Michaelides M, Aligianis IA, Ainsworth JR, Mollon JD, Maher ER, Moore AT and Hunt DM. (2004) Achromatopsia caused by novel mutations in both CNGA3 and CNGB3. J Med Genet 41: e20 [PMID:14757870]

118. Kalloniatis M and Fletcher EL. (2004) Retinitis pigmentosa: understanding the clinical presentation, mechanisms and treatment options. Clin Exp Optom 87: 65-80 [PMID:15040773]

119. Kanyshkova T, Meuth P, Bista P, Liu Z, Ehling P, Caputi L, Doengi M, Chetkovich DM, Pape HC and Budde T. (2012) Differential regulation of HCN channel isoform expression in thalamic neurons of epileptic and non-epileptic rat strains. Neurobiol Dis 45: 450-61 [PMID:21945537]

120. Kaupp UB, Niidome T, Tanabe T, Terada S, Bönigk W, Stühmer W, Cook NJ, Kangawa K, Matsuo $\mathrm{H}$ and Hirose T. (1989) Primary structure and functional expression from complementary DNA of the rod photoreceptor cyclic GMP-gated channel. Nature 342: 762-6 [PMID:2481236]

121. Kaupp UB and Seifert R. (2002) Cyclic nucleotide-gated ion channels. Physiol Rev 82: 769-824 [PMID:12087135]

122. Kaupp UB and Seifert R. (2001) Molecular diversity of pacemaker ion channels. Annu Rev Physiol 63: 235-57 [PMID:11181956]

123. Kelliher KR, Ziesmann J, Munger SD, Reed RR and Zufall F. (2003) Importance of the CNGA4 channel gene for odor discrimination and adaptation in behaving mice. Proc Natl Acad Sci USA 100: 4299-304 [PMID:12649326]

124. Khan NW, Wissinger B, Kohl S and Sieving PA. (2007) CNGB3 achromatopsia with progressive loss of residual cone function and impaired rod-mediated function. Invest Ophthalmol Vis Sci $\mathbf{4 8}$ : 3864-71 [PMID:17652762]

125. Kim CS, Chang PY and Johnston D. (2012) Enhancement of dorsal hippocampal activity by knockdown of HCN1 channels leads to anxiolytic- and antidepressant-like behaviors. Neuron 75: 503-16 [PMID:22884333]

126. Kimura K, Kitano J, Nakajima Y and Nakanishi S. (2004) Hyperpolarization-activated, cyclic nucleotide-gated HCN2 cation channel forms a protein assembly with multiple neuronal scaffold proteins in distinct modes of protein-protein interaction. Genes Cells 9: 631-40 [PMID:15265006]

127. Kingston PA, Zufall F and Barnstable CJ. (1999) Widespread expression of olfactory cyclic nucleotide-gated channel genes in rat brain: implications for neuronal signalling. Synapse 32: 112 [PMID:10188632]

128. Kizhatil K, Baker SA, Arshavsky VY and Bennett V. (2009) Ankyrin-G promotes cyclic nucleotide- 
gated channel transport to rod photoreceptor sensory cilia. Science 323: 1614-7

[PMID:19299621]

129. Knaus A, Zong X, Beetz N, Jahns R, Lohse MJ, Biel M and Hein L. (2007) Direct inhibition of cardiac hyperpolarization-activated cyclic nucleotide-gated pacemaker channels by clonidine. Circulation 115: 872-80 [PMID:17261653]

130. Koch U, Braun M, Kapfer C and Grothe B. (2004) Distribution of HCN1 and HCN2 in rat auditory brainstem nuclei. Eur J Neurosci 20: 79-91 [PMID:15245481]

131. Koeppen K, Reuter P, Kohl S, Baumann B, Ladewig T and Wissinger B. (2008) Functional analysis of human CNGA3 mutations associated with colour blindness suggests impaired surface expression of channel mutants A3(R427C) and A3(R563C). Eur J Neurosci 27: 2391-401 [PMID:18445228]

132. Kohl S, Baumann B, Broghammer M, Jägle H, Sieving P, Kellner U, Spegal R, Anastasi M, Zrenner E and Sharpe LT et al.. (2000) Mutations in the CNGB3 gene encoding the beta-subunit of the cone photoreceptor cGMP-gated channel are responsible for achromatopsia (ACHM3) linked to chromosome 8q21. Hum Mol Genet 9: 2107-16 [PMID:10958649]

133. Kohl S, Marx T, Giddings I, Jägle H, Jacobson SG, Apfelstedt-Sylla E, Zrenner E, Sharpe LT and Wissinger B. (1998) Total colourblindness is caused by mutations in the gene encoding the alpha-subunit of the cone photoreceptor cGMP-gated cation channel. Nat Genet 19: 257-9 [PMID:9662398]

134. Kohl S, Varsanyi B, Antunes GA, Baumann B, Hoyng CB, Jägle H, Rosenberg T, Kellner U, Lorenz B and Salati R et al.. (2005) CNGB3 mutations account for 50\% of all cases with autosomal recessive achromatopsia. Eur J Hum Genet 13: 302-8 [PMID:15657609]

135. Kole MH, Bräuer AU and Stuart GJ. (2007) Inherited cortical HCN1 channel loss amplifies dendritic calcium electrogenesis and burst firing in a rat absence epilepsy model. $J$ Physiol (Lond.) 578: 507-25 [PMID:17095562]

136. Kondo H, Qin M, Mizota A, Kondo M, Hayashi H, Hayashi K, Oshima K, Tahira T and Hayashi K. (2004) A homozygosity-based search for mutations in patients with autosomal recessive retinitis pigmentosa, using microsatellite markers. Invest Ophthalmol Vis Sci 45: 4433-9 [PMID:15557452]

137. Körschen HG, Illing M, Seifert R, Sesti F, Williams A, Gotzes S, Colville C, Müller F, Dosé A and Godde M et al.. (1995) A $240 \mathrm{kDa}$ protein represents the complete beta subunit of the cyclic nucleotide-gated channel from rod photoreceptor. Neuron 15: 627-36 [PMID:7546742]

138. Laish-Farkash A, Glikson M, Brass D, Marek-Yagel D, Pras E, Dascal N, Antzelevitch C, Nof E, Reznik H and Eldar M et al.. (2010) A novel mutation in the HCN4 gene causes symptomatic sinus bradycardia in Moroccan Jews. J Cardiovasc Electrophysiol 21: 1365-72 [PMID:20662977]

139. Lee $\mathrm{CH}$ and MacKinnon R. (2017) Structures of the Human HCN1 Hyperpolarization-Activated Channel. Cell 168: 111-120.e11 [PMID:28086084]

140. Lee CH and MacKinnon R. (2019) Voltage Sensor Movements during Hyperpolarization in the HCN Channel. Cell 179: 1582-1589.e7 [PMID:31787376]

141. Lee HM, Park YS, Kim W and Park CS. (2001) Electrophysiological characteristics of rat gustatory cyclic nucleotide--gated channel expressed in Xenopus oocytes. J Neurophysiol 85: 2335-49 [PMID:11387380]

142. Leinders-Zufall T and Zufall F. (1995) Block of cyclic nucleotide-gated channels in salamander olfactory receptor neurons by the guanylyl cyclase inhibitor LY83583. J Neurophysiol 74: 275962 [PMID:8747232]

143. Lewis AS, Estep CM and Chetkovich DM. (2010) The fast and slow ups and downs of HCN channel regulation. Channels (Austin) 4: 215-31 [PMID:20305382]

144. Lewis AS, Schwartz E, Chan CS, Noam Y, Shin M, Wadman WJ, Surmeier DJ, Baram TZ, Macdonald RL and Chetkovich DM. (2009) Alternatively spliced isoforms of TRIP8b differentially control h channel trafficking and function. J Neurosci 29: 6250-65 [PMID:19439603]

145. Lewis AS, Vaidya SP, Blaiss CA, Liu Z, Stoub TR, Brager DH, Chen X, Bender RA, Estep CM and Popov AB et al.. (2011) Deletion of the hyperpolarization-activated cyclic nucleotide-gated channel auxiliary subunit TRIP8b impairs hippocampal Ih localization and function and promotes antidepressant behavior in mice. J Neurosci 31: 7424-40 [PMID:21593326]

146. Li M, Zhou X, Wang S, Michailidis I, Gong Y, Su D, Li H, Li X and Yang J. (2017) Structure of a eukaryotic cyclic-nucleotide-gated channel. Nature 542: 60-65 [PMID:28099415]

147. Liman ER and Buck LB. (1994) A second subunit of the olfactory cyclic nucleotide-gated channel confers high sensitivity to cAMP. Neuron 13: 611-21 [PMID:7522482]

148. Lin YC, Huang J, Zhang Q, Hollander JM, Frisbee JC, Martin KH, Nestor C, Goodman R and Yu HG. (2010) Inactivation of L-type calcium channel modulated by HCN2 channel. Am J Physiol, Cell Physiol 298: C1029-37 [PMID:20164379]

149. Liu M, Chen TY, Ahamed B, Li J and Yau KW. (1994) Calcium-calmodulin modulation of the olfactory cyclic nucleotide-gated cation channel. Science 266: 1348-54 [PMID:7526466]

150. Lolicato M, Nardini M, Gazzarrini S, Möller S, Bertinetti D, Herberg FW, Bolognesi M, Martin H, Fasolini M and Bertrand JA et al.. (2011) Tetramerization dynamics of C-terminal domain 
underlies isoform-specific cAMP gating in hyperpolarization-activated cyclic nucleotide-gated channels. J Biol Chem 286: 44811-20 [PMID:22006928]

151. Ludwig A, Budde T, Stieber J, Moosmang S, Wahl C, Holthoff K, Langebartels A, Wotjak C, Munsch T, Zong X, Feil S, Feil R, Lancel M, Chien KR, Konnerth A, Pape HC, Biel M and Hofmann F. (2003) Absence epilepsy and sinus dysrhythmia in mice lacking the pacemaker channel HCN2. EMBO J 22: 216-24 [PMID:12514127]

152. Ludwig A, Zong X, Hofmann F and Biel M. (1999) Structure and function of cardiac pacemaker channels. Cell Physiol Biochem 9: 179-86 [PMID:10575196]

153. Ludwig A, Zong X, Jeglitsch M, Hofmann F and Biel M. (1998) A family of hyperpolarizationactivated mammalian cation channels. Nature 393: 587-91 [PMID:9634236]

154. Ludwig A, Zong X, Stieber J, Hullin R, Hofmann F and Biel M. (1999) Two pacemaker channels from human heart with profoundly different activation kinetics. EMBO J 18: 2323-9 [PMID:10228147]

155. Lyashchenko AK, Redd KJ, Yang J and Tibbs GR. (2007) Propofol inhibits HCN1 pacemaker channels by selective association with the closed states of the membrane embedded channel core. J Physiol (Lond.) 583: 37-56 [PMID:17569731]

156. Matt L, Michalakis S, Hofmann F, Hammelmann V, Ludwig A, Biel M and Kleppisch T. (2011) HCN2 channels in local inhibitory interneurons constrain LTP in the hippocampal direct perforant path. Cell Mol Life Sci 68: 125-37 [PMID:20623157]

157. Matulef K and Zagotta WN. (2003) Cyclic nucleotide-gated ion channels. Annu Rev Cell Dev Biol 19: 23-44 [PMID:14570562]

158. Matveev AV, Quiambao AB, Browning Fitzgerald J and Ding XQ. (2008) Native cone photoreceptor cyclic nucleotide-gated channel is a heterotetrameric complex comprising both CNGA3 and CNGB3: a study using the cone-dominant retina of Nrl-/- mice. J Neurochem 106: 2042-55 [PMID:18665891]

159. Meuth SG, Kanyshkova T, Meuth P, Landgraf P, Munsch T, Ludwig A, Hofmann F, Pape HC and Budde T. (2006) Membrane resting potential of thalamocortical relay neurons is shaped by the interaction among TASK3 and HCN2 channels. J Neurophysiol 96: 1517-29 [PMID:16760342]

160. Meyer MR, Angele A, Kremmer E, Kaupp UB and Muller F. (2000) A cGMP-signaling pathway in a subset of olfactory sensory neurons. Proc Natl Acad Sci USA 97: 10595-600 [PMID:10984544]

161. Michaelides M, Aligianis IA, Ainsworth JR, Good P, Mollon JD, Maher ER, Moore AT and Hunt DM. (2004) Progressive cone dystrophy associated with mutation in CNGB3. Invest Ophthalmol Vis Sci 45: 1975-82 [PMID:15161866]

162. Michalakis S, Geiger H, Haverkamp S, Hofmann F, Gerstner A and Biel M. (2005) Impaired opsin targeting and cone photoreceptor migration in the retina of mice lacking the cyclic nucleotide-gated channel CNGA3. Invest Ophthalmol Vis Sci 46: 1516-24 [PMID:15790924]

163. Michalakis S, Reisert J, Geiger H, Wetzel C, Zong X, Bradley J, Spehr M, Hüttl S, Gerstner A and Pfeifer A et al.. (2006) Loss of CNGB1 protein leads to olfactory dysfunction and subciliary cyclic nucleotide-gated channel trapping. J Biol Chem 281: 35156-66 [PMID:16980309]

164. Michalakis S, Zong X, Becirovic E, Hammelmann V, Wein T, Wanner KT and Biel M. (2011) The glutamic acid-rich protein is a gating inhibitor of cyclic nucleotide-gated channels. J Neurosci 31: 133-41 [PMID:21209198]

165. Michels G, Er F, Khan I, Südkamp M, Herzig S and Hoppe UC. (2005) Single-channel properties support a potential contribution of hyperpolarization-activated cyclic nucleotide-gated channels and If to cardiac arrhythmias. Circulation 111: 399-404 [PMID:15687126]

166. Michels G, Er F, Khan IF, Endres-Becker J, Brandt MC, Gassanov N, Johns DC and Hoppe UC. (2008) K+ channel regulator KCR1 suppresses heart rhythm by modulating the pacemaker current If. PLOS ONE 3: e1511 [PMID:18231597]

167. Milanesi R, Baruscotti M, Gnecchi-Ruscone T and DiFrancesco D. (2006) Familial sinus bradycardia associated with a mutation in the cardiac pacemaker channel. $N$ Engl J Med 354: 151-7 [PMID:16407510]

168. Misaka T, Ishimaru Y, Iwabuchi K, Kusakabe Y, Arai S, Emori Y and Abe K. (1999) A gustatory cyclic nucleotide-gated channels CNGgust, is expressed in the retina. Neuroreport 10: 743-6 [PMID:10208541]

169. Misaka T, Kusakabe Y, Emori Y, Gonoi T, Arai S and Abe K. (1997) Taste buds have a cyclic nucleotide-activated channel, CNGgust. J Biol Chem 272: 22623-9 [PMID:9278419]

170. Mistrík P, Mader R, Michalakis S, Weidinger M, Pfeifer A and Biel M. (2005) The murine HCN3 gene encodes a hyperpolarization-activated cation channel with slow kinetics and unique response to cyclic nucleotides. J Biol Chem 280: 27056-61 [PMID:15923185]

171. Mobley AS, Miller AM, Araneda RC, Maurer LR, Müller F and Greer CA. (2010) Hyperpolarization-activated cyclic nucleotide-gated channels in olfactory sensory neurons regulate axon extension and glomerular formation. J Neurosci 30: 16498-508 [PMID:21147989]

172. Molday RS and Molday LL. (1998) Molecular properties of the cGMP-gated channel of rod photoreceptors. Vision Res 38: 1315-23 [PMID:9666999]

173. Monteggia LM, Eisch AJ, Tang MD, Kaczmarek LK and Nestler EJ. (2000) Cloning and 
localization of the hyperpolarization-activated cyclic nucleotide-gated channel family in rat brain. Brain Res Mol Brain Res 81: 129-39 [PMID:11000485]

174. Moosmang S, Biel M, Hofmann F and Ludwig A. (1999) Differential distribution of four hyperpolarization-activated cation channels in mouse brain. Biol Chem 380: 975-80 [PMID:10494850]

175. Moosmang S, Stieber J, Zong X, Biel M, Hofmann F and Ludwig A. (2001) Cellular expression and functional characterization of four hyperpolarization-activated pacemaker channels in cardiac and neuronal tissues. Eur J Biochem 268: 1646-52 [PMID:11248683]

176. Much B, Wahl-Schott C, Zong X, Schneider A, Baumann L, Moosmang S, Ludwig A and Biel M. (2003) Role of subunit heteromerization and N-linked glycosylation in the formation of functional hyperpolarization-activated cyclic nucleotide-gated channels. J Biol Chem 278: 43781-6 [PMID:12928435]

177. Munger SD, Lane AP, Zhong H, Leinders-Zufall T, Yau KW, Zufall F and Reed RR. (2001) Central role of the CNGA4 channel subunit in $\mathrm{Ca} 2+$-calmodulin-dependent odor adaptation. Science 294: 2172-5 [PMID:11739959]

178. Männikkö R, Elinder F and Larsson HP. (2002) Voltage-sensing mechanism is conserved among ion channels gated by opposite voltages. Nature 419: 837-41 [PMID:12397358]

179. Müller F, Scholten A, Ivanova E, Haverkamp S, Kremmer E and Kaupp UB. (2003) HCN channels are expressed differentially in retinal bipolar cells and concentrated at synaptic terminals. Eur J Neurosci 17: 2084-96 [PMID:12786975]

180. Nache V, Zimmer T, Wongsamitkul N, Schmauder R, Kusch J, Reinhardt L, Bönigk W, Seifert R, Biskup C and Schwede F et al.. (2012) Differential regulation by cyclic nucleotides of the CNGA4 and CNGB1b subunits in olfactory cyclic nucleotide-gated channels. Sci Signal 5: ra48 [PMID:22786723]

181. Nakamura T and Gold GH. (1987) A cyclic nucleotide-gated conductance in olfactory receptor cilia. Nature 325: 442-4 [PMID:3027574]

182. Nishiguchi KM, Sandberg MA, Gorji N, Berson EL and Dryja TP. (2005) Cone cGMP-gated channel mutations and clinical findings in patients with achromatopsia, macular degeneration, and other hereditary cone diseases. Hum Mutat 25: 248-58 [PMID:15712225]

183. Nof E, Luria D, Brass D, Marek D, Lahat H, Reznik-Wolf H, Pras E, Dascal N, Eldar M and Glikson M. (2007) Point mutation in the HCN4 cardiac ion channel pore affecting synthesis, trafficking, and functional expression is associated with familial asymptomatic sinus bradycardia. Circulation 116: 463-70 [PMID:17646576]

184. Nolan MF, Dudman JT, Dodson PD and Santoro B. (2007) HCN1 channels control resting and active integrative properties of stellate cells from layer II of the entorhinal cortex. J Neurosci 27: 12440-51 [PMID:18003822]

185. Nolan MF, Malleret G, Dudman JT, Buhl DL, Santoro B, Gibbs E, Vronskaya S, Buzsáki G, Siegelbaum SA and Kandel ER et al.. (2004) A behavioral role for dendritic integration: HCN1 channels constrain spatial memory and plasticity at inputs to distal dendrites of CA1 pyramidal neurons. Cell 119: 719-32 [PMID:15550252]

186. Nolan MF, Malleret G, Lee KH, Gibbs E, Dudman JT, Santoro B, Yin D, Thompson RF, Siegelbaum SA and Kandel ER et al.. (2003) The hyperpolarization-activated HCN1 channel is important for motor learning and neuronal integration by cerebellar Purkinje cells. Cell 115: 551-64 [PMID:14651847]

187. Notomi T and Shigemoto R. (2004) Immunohistochemical localization of Ih channel subunits, HCN1-4, in the rat brain. J Comp Neurol 471: 241-76 [PMID:14991560]

188. Oh YJ, Na J, Jeong JH, Park DK, Park KH, Ko JS and Kim DS. (2012) Alterations in hyperpolarization-activated cyclic nucleotidegated cation channel (HCN) expression in the hippocampus following pilocarpine-induced status epilepticus. BMB Rep 45: 635-40 [PMID:23187002]

189. Okada A, Ueyama H, Toyoda F, Oda S, Ding WG, Tanabe S, Yamade S, Matsuura H, Ohkubo I and Kani K. (2004) Functional role of hCngb3 in regulation of human cone cng channel: effect of rod monochromacy-associated mutations in hCNGB3 on channel function. Invest Ophthalmol Vis Sci 45: 2324-32 [PMID:15223812]

190. Paloma E, Martínez-Mir A, García-Sandoval B, Ayuso C, Vilageliu L, Gonzàlez-Duarte R and Balcells S. (2002) Novel homozygous mutation in the alpha subunit of the rod cGMP gated channel (CNGA1) in two Spanish sibs affected with autosomal recessive retinitis pigmentosa. $J$ Med Genet 39: E66 [PMID:12362048]

191. Paoletti P, Young EC and Siegelbaum SA. (1999) C-Linker of cyclic nucleotide-gated channels controls coupling of ligand binding to channel gating. J Gen Physiol 113: 17-34 [PMID:9874685]

192. Pape HC. (1996) Queer current and pacemaker: the hyperpolarization-activated cation current in neurons. Annu Rev Physiol 58: 299-327 [PMID:8815797]

193. Papp I, Holló K and Antal M. (2010) Plasticity of hyperpolarization-activated and cyclic nucleotid-gated cation channel subunit 2 expression in the spinal dorsal horn in inflammatory pain. Eur J Neurosci 32: 1193-201 [PMID:20726890] 
194. Peng C, Rich ED, Thor CA and Varnum MD. (2003) Functionally important calmodulin-binding sites in both NH2- and $\mathrm{COOH}$-terminal regions of the cone photoreceptor cyclic nucleotidegated channel CNGB3 subunit. J Biol Chem 278: 24617-23 [PMID:12730238]

195. Peng C, Rich ED and Varnum MD. (2004) Subunit configuration of heteromeric cone cyclic nucleotide-gated channels. Neuron 42: 401-10 [PMID:15134637]

196. Peng C, Rich ED and Varnum MD. (2003) Achromatopsia-associated mutation in the human cone photoreceptor cyclic nucleotide-gated channel CNGB3 subunit alters the ligand sensitivity and pore properties of heteromeric channels. J Biol Chem 278: 34533-40 [PMID:12815043]

197. Pian P, Bucchi A, Robinson RB and Siegelbaum SA. (2006) Regulation of gating and rundown of HCN hyperpolarization-activated channels by exogenous and endogenous PIP2. J Gen Physiol 128: 593-604 [PMID:17074978]

198. Pifferi S, Boccaccio A and Menini A. (2006) Cyclic nucleotide-gated ion channels in sensory transduction. FEBS Lett 580: 2853-9 [PMID:16631748]

199. Piskorowski R, Santoro B and Siegelbaum SA. (2011) TRIP8b splice forms act in concert to regulate the localization and expression of HCN1 channels in CA1 pyramidal neurons. Neuron 70: 495-509 [PMID:21555075]

200. Pittler SJ, Lee AK, Altherr MR, Howard TA, Seldin MF, Hurwitz RL, Wasmuth JJ and Baehr W. (1992) Primary structure and chromosomal localization of human and mouse rod photoreceptor cGMP-gated cation channel. J Biol Chem 267: 6257-62 [PMID:1372902]

201. Poetsch A, Molday LL and Molday RS. (2001) The cGMP-gated channel and related glutamic acid-rich proteins interact with peripherin-2 at the rim region of rod photoreceptor disc membranes. J Biol Chem 276: 48009-16 [PMID:11641407]

202. Postea O and Biel M. (2011) Exploring HCN channels as novel drug targets. Nat Rev Drug Discov 10: 903-14 [PMID:22094868]

203. Qu J, Altomare C, Bucchi A, DiFrancesco D and Robinson RB. (2002) Functional comparison of HCN isoforms expressed in ventricular and HEK 293 cells. Pflugers Arch 444: 597-601 [PMID:12194012]

204. Qu J, Kryukova Y, Potapova IA, Doronin SV, Larsen M, Krishnamurthy G, Cohen IS and Robinson RB. (2004) MiRP1 modulates HCN2 channel expression and gating in cardiac myocytes. J Biol Chem 279: 43497-502 [PMID:15292247]

205. Raes A, Van de Vijver G, Goethals M and van Bogaert PP. (1998) Use-dependent block of Ih in mouse dorsal root ganglion neurons by sinus node inhibitors. Br J Pharmacol 125: 741-50 [PMID:9831910]

206. Ramakrishnan NA, Drescher MJ, Barretto RL, Beisel KW, Hatfield JS and Drescher DG. (2009) Calcium-dependent binding of HCN1 channel protein to hair cell stereociliary tip link protein protocadherin 15 CD3. J Biol Chem 284: 3227-38 [PMID:19008224]

207. Ramakrishnan NA, Drescher MJ, Khan KM, Hatfield JS and Drescher DG. (2012) HCN1 and HCN2 proteins are expressed in cochlear hair cells: HCN1 can form a ternary complex with protocadherin $15 \mathrm{CD} 3$ and F-actin-binding filamin A or can interact with HCN2.J Biol Chem 287: 37628-46 [PMID:22948144]

208. Rebrik TI, Botchkina I, Arshavsky VY, Craft CM and Korenbrot JI. (2012) CNG-modulin: a novel Ca-dependent modulator of ligand sensitivity in cone photoreceptor cGMP-gated ion channels. $J$ Neurosci 32: 3142-53 [PMID:22378887]

209. Reuter P, Koeppen K, Ladewig T, Kohl S, Baumann B, Wissinger B and Achromatopsia Clinical Study Group. (2008) Mutations in CNGA3 impair trafficking or function of cone cyclic nucleotide-gated channels, resulting in achromatopsia. Hum Mutat 29: 1228-36 [PMID:18521937]

210. Robinson RB and Siegelbaum SA. (2003) Hyperpolarization-activated cation currents: from molecules to physiological function. Annu Rev Physiol 65: 453-80 [PMID:12471170]

211. Rosenbaum T, Gordon-Shaag A, Islas LD, Cooper J, Munari M and Gordon SE. (2004) Statedependent block of CNG channels by dequalinium. J Gen Physiol 123: 295-304 [PMID:14981138]

212. Rosenbaum T, Islas LD, Carlson AE and Gordon SE. (2003) Dequalinium: a novel, high-affinity blocker of CNGA1 channels. J Gen Physiol 121: 37-47 [PMID:12508052]

213. Ruiz ML, London B and Nadal-Ginard B. (1996) Cloning and characterization of an olfactory cyclic nucleotide-gated channel expressed in mouse heart. J Mol Cell Cardiol 28: 1453-61 [PMID:8841933]

214. Santoro B, Grant SG, Bartsch D and Kandel ER. (1997) Interactive cloning with the SH3 domain of N-src identifies a new brain specific ion channel protein, with homology to eag and cyclic nucleotide-gated channels. Proc Natl Acad Sci USA 94: 14815-20 [PMID:9405696]

215. Santoro B, Hu L, Liu H, Saponaro A, Pian P, Piskorowski RA, Moroni A and Siegelbaum SA. (2011) TRIP8b regulates HCN1 channel trafficking and gating through two distinct C-terminal interaction sites. J Neurosci 31: 4074-86 [PMID:21411649]

216. Santoro B, Lee JY, Englot DJ, Gildersleeve S, Piskorowski RA, Siegelbaum SA, Winawer MR and Blumenfeld H. (2010) Increased seizure severity and seizure-related death in mice lacking 
HCN1 channels. Epilepsia 51: 1624-7 [PMID:20384728]

217. Santoro B, Liu DT, Yao H, Bartsch D, Kandel ER, Siegelbaum SA and Tibbs GR. (1998)

Identification of a gene encoding a hyperpolarization-activated pacemaker channel of brain. Cell 93: 717-29 [PMID:9630217]

218. Santoro B, Piskorowski RA, Pian P, Hu L, Liu H and Siegelbaum SA. (2009) TRIP8b splice variants form a family of auxiliary subunits that regulate gating and trafficking of HCN channels in the brain. Neuron 62: 802-13 [PMID:19555649]

219. Santoro B, Wainger BJ and Siegelbaum SA. (2004) Regulation of HCN channel surface expression by a novel C-terminal protein-protein interaction. J Neurosci 24: 10750-62 [PMID:15564593]

220. Santos-Vera B, Vázquez-Torres R, Marrero HG, Acevedo JM, Arencibia-Albite F, VélezHernández ME, Miranda JD and Jiménez-Rivera CA. (2013) Cocaine sensitization increases I h current channel subunit $2\left(\mathrm{HCN}_{2}\right)$ protein expression in structures of the mesocorticolimbic system. J Mol Neurosci 50: 234-45 [PMID:23203153]

221. Saponaro A, Pauleta SR, Cantini F, Matzapetakis M, Hammann C, Donadoni C, Hu L, Thiel G, Banci L and Santoro B et al.. (2014) Structural basis for the mutual antagonism of cAMP and TRIP8b in regulating HCN channel function. Proc Natl Acad Sci U S A 111: 14577-82 [PMID:25197093]

222. Sartiani L, Romanelli MN, Mugelli A and Cerbai E. (2015) Updates on HCN Channels in the Heart: Function, Dysfunction and Pharmacology. Curr Drug Targets 16: 868-76 [PMID:26028050]

223. Sautter A, Biel M and Hofmann F. (1997) Molecular cloning of cyclic nucleotide-gated cation channel subunits from rat pineal gland. Brain Res Mol Brain Res 48: 171-5 [PMID:9379842]

224. Sautter A, Zong X, Hofmann F and Biel M. (1998) An isoform of the rod photoreceptor cyclic nucleotide-gated channel beta subunit expressed in olfactory neurons. Proc Natl Acad Sci USA 95: 4696-701 [PMID:9539801]

225. Schorderet DF, Iouranova A, Favez T, Tiab L and Escher P. (2013) IROme, a new highthroughput molecular tool for the diagnosis of inherited retinal dystrophies. Biomed Res Int 2013: 198089 [PMID:23484092]

226. Schulze-Bahr E, Neu A, Friederich P, Kaupp UB, Breithardt G, Pongs O and Isbrandt D. (2003) Pacemaker channel dysfunction in a patient with sinus node disease. J Clin Invest 111: 1537-45 [PMID:12750403]

227. Seeliger MW, Brombas A, Weiler R, Humphries P, Knop G, Tanimoto N and Müller F. (2011) Modulation of rod photoreceptor output by HCN1 channels is essential for regular mesopic cone vision. Nat Commun 2: 532 [PMID:22068599]

228. Seifert R, Scholten A, Gauss R, Mincheva A, Lichter P and Kaupp UB. (1999) Molecular characterization of a slowly gating human hyperpolarization-activated channel predominantly expressed in thalamus, heart, and testis. Proc Natl Acad Sci USA 96: 9391-6 [PMID:10430953]

229. Selvakumar D, Drescher MJ, Dowdall JR, Khan KM, Hatfield JS, Ramakrishnan NA and Drescher DG. (2012) CNGA3 is expressed in inner ear hair cells and binds to an intracellular C-terminus domain of EMILIN1. Biochem J 443: 463-76 [PMID:22248097]

230. Selvakumar D, Drescher MJ and Drescher DG. (2013) Cyclic nucleotide-gated channel $\alpha-3$ (CNGA3) interacts with stereocilia tip-link cadherin 23 + exon 68 or alternatively with myosin VIIa, two proteins required for hair cell mechanotransduction. J Biol Chem 288: 7215-29 [PMID:23329832]

231. Shi W, Wymore R, Yu H, Wu J, Wymore RT, Pan Z, Robinson RB, Dixon JE, McKinnon D and Cohen IS. (1999) Distribution and prevalence of hyperpolarization-activated cation channel (HCN) mRNA expression in cardiac tissues. Circ Res 85: e1-6 [PMID:10400919]

232. Shuart NG, Haitin Y, Camp SS, Black KD and Zagotta WN. (2011) Molecular mechanism for 3:1 subunit stoichiometry of rod cyclic nucleotide-gated ion channels. Nat Commun 2: 457 [PMID:21878911]

233. Simpson DA, Clark GR, Alexander S, Silvestri G and Willoughby CE. (2011) Molecular diagnosis for heterogeneous genetic diseases with targeted high-throughput DNA sequencing applied to retinitis pigmentosa. $J$ Med Genet 48: 145-51 [PMID:21147909]

234. Song J, Smaoui N, Ayyagari R, Stiles D, Benhamed S, MacDonald IM, Daiger SP, Tumminia SJ, Hejtmancik F and Wang X. (2011) High-throughput retina-array for screening 93 genes involved in inherited retinal dystrophy. Invest Ophthalmol Vis Sci 52: 9053-60 [PMID:22025579]

235. Stevens DR, Seifert R, Bufe B, Müller F, Kremmer E, Gauss R, Meyerhof W, Kaupp UB and Lindemann B. (2001) Hyperpolarization-activated channels HCN1 and HCN4 mediate responses to sour stimuli. Nature 413: 631-5 [PMID:11675786]

236. Stieber J, Herrmann S, Feil S, Löster J, Feil R, Biel M, Hofmann F and Ludwig A. (2003) The hyperpolarization-activated channel HCN4 is required for the generation of pacemaker action potentials in the embryonic heart. Proc Natl Acad Sci USA 100: 15235-40 [PMID:14657344]

237. Stieber J, Stöckl G, Herrmann S, Hassfurth B and Hofmann F. (2005) Functional expression of the human HCN3 channel. J Biol Chem 280: 34635-43 [PMID:16043489] 
238. Stieber J, Wieland K, Stöckl G, Ludwig A and Hofmann F. (2006) Bradycardic and proarrhythmic properties of sinus node inhibitors. Mol Pharmacol 69: 1328-37 [PMID:16387796]

239. Sundin OH, Yang JM, Li Y, Zhu D, Hurd JN, Mitchell TN, Silva ED and Maumenee IH. (2000) Genetic basis of total colourblindness among the Pingelapese islanders. Nat Genet 25: 289-93 [PMID:10888875]

240. Surges R, Kukley M, Brewster A, Rüschenschmidt C, Schramm J, Baram TZ, Beck H and Dietrich D. (2012) Hyperpolarization-activated cation current Ih of dentate gyrus granule cells is upregulated in human and rat temporal lobe epilepsy. Biochem Biophys Res Commun 420: 15660 [PMID:22405820]

241. Tang B, Sander T, Craven KB, Hempelmann A and Escayg A. (2008) Mutation analysis of the hyperpolarization-activated cyclic nucleotide-gated channels HCN1 and HCN2 in idiopathic generalized epilepsy. Neurobiol Dis 29: 59-70 [PMID:17931874]

242. Thiadens AA, Roosing S, Collin RW, van Moll-Ramirez N, van Lith-Verhoeven JJ, van Schooneveld MJ, den Hollander AI, van den Born LI, Hoyng CB and Cremers FP et al.. (2010) Comprehensive analysis of the achromatopsia genes CNGA3 and CNGB3 in progressive cone dystrophy. Ophthalmology 117: 825-30.e1 [PMID:20079539]

243. Thiadens AA, Slingerland NW, Roosing S, van Schooneveld MJ, van Lith-Verhoeven JJ, van MollRamirez N, van den Born LI, Hoyng CB, Cremers FP and Klaver CC. (2009) Genetic etiology and clinical consequences of complete and incomplete achromatopsia. Ophthalmology 116: 19849.e1 [PMID:19592100]

244. Trudeau MC and Zagotta WN. (2002) An intersubunit interaction regulates trafficking of rod cyclic nucleotide-gated channels and is disrupted in an inherited form of blindness. Neuron 34: 197-207 [PMID:11970862]

245. Tu E, Waterhouse L, Duflou J, Bagnall RD and Semsarian C. (2011) Genetic analysis of hyperpolarization-activated cyclic nucleotide-gated cation channels in sudden unexpected death in epilepsy cases. Brain Pathol 21: 692-8 [PMID:21615589]

246. Ueda K, Nakamura K, Hayashi T, Inagaki N, Takahashi M, Arimura T, Morita H, Higashiuesato Y, Hirano Y and Yasunami M et al.. (2004) Functional characterization of a trafficking-defective HCN4 mutation, D553N, associated with cardiac arrhythmia. J Biol Chem 279: 27194-8 [PMID:15123648]

247. Ulens C and Tytgat J. (2001) Functional heteromerization of HCN1 and HCN2 pacemaker channels. J Biol Chem 276: 6069-72 [PMID:11133998]

248. Ungerer N, Mücke N, Broecker J, Keller S, Frings S and Möhrlen F. (2011) Distinct binding properties distinguish LQ-type calmodulin-binding domains in cyclic nucleotide-gated channels. Biochemistry 50: 3221-8 [PMID:21413724]

249. Varsányi B, Wissinger B, Kohl S, Koeppen K and Farkas A. (2005) Clinical and genetic features of Hungarian achromatopsia patients. Mol Vis 11: 996-1001 [PMID:16319819]

250. Vemana S, Pandey S and Larsson HP. (2008) Intracellular Mg2+ is a voltage-dependent pore blocker of HCN channels. Am J Physiol, Cell Physiol 295: C557-65 [PMID:18579800]

251. Verkerk AO and Wilders R. (2015) Pacemaker activity of the human sinoatrial node: an update on the effects of mutations in HCN4 on the hyperpolarization-activated current. Int J Mol Sci 16: 3071-94 [PMID:25642760]

252. Wahl-Schott C, Fenske S and Biel M. (2014) HCN channels: new roles in sinoatrial node function. Curr Opin Pharmacol 15: 83-90 [PMID:24441197]

253. Wainger BJ, DeGennaro M, Santoro B, Siegelbaum SA and Tibbs GR. (2001) Molecular mechanism of cAMP modulation of HCN pacemaker channels. Nature 411: 805-10 [PMID:11459060]

254. Wan Y. (2008) Involvement of hyperpolarization-activated, cyclic nucleotide-gated cation channels in dorsal root ganglion in neuropathic pain. Sheng Li Xue Bao 60: 579-80 [PMID:18958363]

255. Wang J, Chen S and Siegelbaum SA. (2001) Regulation of hyperpolarization-activated HCN channel gating and cAMP modulation due to interactions of $\mathrm{COOH}$ terminus and core transmembrane regions. J Gen Physiol 118: 237-50 [PMID:11524455]

256. Wei JY, Cohen ED and Barnstable CJ. (1997) Direct blockade of both cloned rat rod photoreceptor cyclic nucleotide-gated non-selective cation (CNG) channel alpha-subunit and native CNG channels from Xenopus rod outer segments by H-8, a non-specific cyclic nucleotidedependent protein kinase inhibitor. Neurosci Lett 233: 37-40 [PMID:9324234]

257. Weitz D, Ficek N, Kremmer E, Bauer PJ and Kaupp UB. (2002) Subunit stoichiometry of the CNG channel of rod photoreceptors. Neuron 36: 881-9 [PMID:12467591]

258. Weyand I, Godde M, Frings S, Weiner J, Müller F, Altenhofen W, Hatt H and Kaupp UB. (1994) Cloning and functional expression of a cyclic-nucleotide-gated channel from mammalian sperm. Nature 368: 859-63 [PMID:7512693]

259. Wiesner B, Weiner J, Middendorff R, Hagen V, Kaupp UB and Weyand I. (1998) Cyclic nucleotide-gated channels on the flagellum control Ca2+ entry into sperm. J Cell Biol 142: 47384 [PMID:9679145] 
260. Wilkars W, Liu Z, Lewis AS, Stoub TR, Ramos EM, Brandt N, Nicholson DA, Chetkovich DM and Bender RA. (2012) Regulation of axonal HCN1 trafficking in perforant path involves expression of specific TRIP8b isoforms. PLoS ONE 7: e32181 [PMID:22363812]

261. Wissinger B, Gamer D, Jägle H, Giorda R, Marx T, Mayer S, Tippmann S, Broghammer M, Jurklies B, Rosenberg T, Jacobson SG, Sener EC, Tatlipinar S, Hoyng CB, Castellan C, Bitoun P, Andreasson S, Rudolph G, Kellner U, Lorenz B, Wolff G, Verellen-Dumoulin C, Schwartz M, Cremers FP, Apfelstedt-Sylla E, Zrenner E, Salati R, Sharpe LT and Kohl S. (2001) CNGA3 mutations in hereditary cone photoreceptor disorders. Am J Hum Genet 69: 722-37 [PMID:11536077]

262. Wissinger B, Müller F, Weyand I, Schuffenhauer S, Thanos S, Kaupp UB and Zrenner E. (1997) Cloning, chromosomal localization and functional expression of the gene encoding the alphasubunit of the cGMP-gated channel in human cone photoreceptors. Eur J Neurosci 9: 2512-21 [PMID:9517456]

263. Wiszniewski W, Lewis RA and Lupski JR. (2007) Achromatopsia: the CNGB3 p.T383fsX mutation results from a founder effect and is responsible for the visual phenotype in the original report of uniparental disomy 14. Hum Genet 121: 433-9 [PMID:17265047]

264. Xia S, Wang Y, Zhang Y, Deng SB, Du JL, Wang XC and She Q. (2010) Dynamic changes in HCN2, HCN4, KCNE1, and KCNE2 expression in ventricular cells from acute myocardial infarction rat hearts. Biochem Biophys Res Commun 395: 330-5 [PMID:20381460]

265. Xiao J, Nguyen TV, Ngui K, Strijbos PJ, Selmer IS, Neylon CB and Furness JB. (2004) Molecular and functional analysis of hyperpolarisation-activated nucleotide-gated (HCN) channels in the enteric nervous system. Neuroscience 129: 603-14 [PMID:15541882]

266. Xu X, Marni F, Wu S, Su Z, Musayev F, Shrestha S, Xie C, Gao W, Liu Q and Zhou L. (2012) Local and global interpretations of a disease-causing mutation near the ligand entry path in hyperpolarization-activated cAMP-gated channel. Structure 20: 2116-23 [PMID:23103389]

267. Xu X, Vysotskaya ZV, Liu Q and Zhou L. (2010) Structural basis for the cAMP-dependent gating in the human HCN4 channel. J Biol Chem 285: 37082-91 [PMID:20829353]

268. Yang S, Xiong CJ, Sun HM, Li XS, Zhang GQ, Wu B and Zhou DS. (2012) The distribution of HCN2-positive cells in the gastrointestinal tract of mice. J Anat 221: 303-10 [PMID:22803609]

269. Yasui K, Liu W, Opthof T, Kada K, Lee JK, Kamiya K and Kodama I. (2001) I(f) current and spontaneous activity in mouse embryonic ventricular myocytes. Circ Res 88: 536-42 [PMID:11249878]

270. Ying SW, Jia F, Abbas SY, Hofmann F, Ludwig A and Goldstein PA. (2007) Dendritic HCN2 channels constrain glutamate-driven excitability in reticular thalamic neurons. J Neurosci 27: 8719-32 [PMID:17687049]

271. Ying SW, Kanda VA, Hu Z, Purtell K, King EC, Abbott GW and Goldstein PA. (2012) Targeted deletion of Kcne2 impairs HCN channel function in mouse thalamocortical circuits. PLoS ONE 7: e42756 [PMID:22880098]

272. Yu WP, Grunwald ME and Yau KW. (1996) Molecular cloning, functional expression and chromosomal localization of a human homolog of the cyclic nucleotide-gated ion channel of retinal cone photoreceptors. FEBS Lett 393: 211-5 [PMID:8814292]

273. Yu X, Chen XW, Zhou P, Yao L, Liu T, Zhang B, Li Y, Zheng H, Zheng LH and Zhang CX et al.. (2007) Calcium influx through If channels in rat ventricular myocytes. Am J Physiol, Cell Physiol 292: C1147-55 [PMID:17065201]

274. Yu X, Duan KL, Shang CF, Yu HG and Zhou Z. (2004) Calcium influx through hyperpolarizationactivated cation channels (I(h) channels) contributes to activity-evoked neuronal secretion. Proc Natl Acad Sci USA 101: 1051-6 [PMID:14724293]

275. Zagotta WN, Olivier NB, Black KD, Young EC, Olson R and Gouaux E. (2003) Structural basis for modulation and agonist specificity of HCN pacemaker channels. Nature 425: 200-5 [PMID:12968185]

276. Zhang Q, Zulfiqar F, Riazuddin SA, Xiao X, Ahmad Z, Riazuddin S and Hejtmancik JF. (2004) Autosomal recessive retinitis pigmentosa in a Pakistani family mapped to CNGA1 with identification of a novel mutation. Mol Vis 10: 884-9 [PMID:15570217]

277. Zhang Y, Liu Y, Qu J, Hardy A, Zhang N, Diao J, Strijbos PJ, Tsushima R, Robinson RB and Gaisano HY et al.. (2009) Functional characterization of hyperpolarization-activated cyclic nucleotide-gated channels in rat pancreatic beta cells. J Endocrinol 203: 45-53 [PMID:19654142]

278. Zheng J, Trudeau MC and Zagotta WN. (2002) Rod cyclic nucleotide-gated channels have a stoichiometry of three CNGA1 subunits and one CNGB1 subunit. Neuron 36: 891-6 [PMID:12467592]

279. Zheng J and Zagotta WN. (2004) Stoichiometry and assembly of olfactory cyclic nucleotide-gated channels. Neuron 42: 411-21 [PMID:15134638]

280. Zhong H, Molday LL, Molday RS and Yau KW. (2002) The heteromeric cyclic nucleotide-gated channel adopts a 3A:1B stoichiometry. Nature 420: 193-8 [PMID:12432397]

281. Zhou C, Douglas JE, Kumar NN, Shu S, Bayliss DA and Chen X. (2013) Forebrain HCN1 
channels contribute to hypnotic actions of ketamine. Anesthesiology 118: 785-95

[PMID:23377220]

282. Zolles G, Wenzel D, Bildl W, Schulte U, Hofmann A, Müller CS, Thumfart JO, Vlachos A, Deller T and Pfeifer A et al.. (2009) Association with the auxiliary subunit PEX5R/Trip8b controls responsiveness of HCN channels to cAMP and adrenergic stimulation. Neuron 62: 814-25 [PMID:19555650]

283. Zong X, Eckert C, Yuan H, Wahl-Schott C, Abicht H, Fang L, Li R, Mistrik P, Gerstner A and Much B et al.. (2005) A novel mechanism of modulation of hyperpolarization-activated cyclic nucleotide-gated channels by Src kinase. J Biol Chem 280: 34224-32 [PMID:16079136]

284. Zong X, Krause S, Chen CC, Krüger J, Gruner C, Cao-Ehlker X, Fenske S, Wahl-Schott C and Biel M. (2012) Regulation of hyperpolarization-activated cyclic nucleotide-gated (HCN) channel activity by cCMP. J Biol Chem 287: 26506-12 [PMID:22715094] 